\title{
Bioregeneration of saturated natural mordenite to reduce iron and manganese in groundwater
}

\author{
Rifka Noor $^{1, *}$, Elda Septiyani ${ }^{1}$, Yuniati Zevi ${ }^{1}$, and Nur Novilina Arifianingsih ${ }^{1}$ \\ ${ }^{1}$ Faculty of Civil and Environmental Engineering, Institut Teknologi Bandung, Indonesia
}

\begin{abstract}
Significant improvement of technologies was developed to remove iron and manganese contamination from ground water. One of the technologies is the use of adsorbents but, recycling of used adsorbents is little to be done. Only a few researchers reported studies that highlighted on recovery of adsorbent through biological processes. In this study, bio-regeneration chosen as a technical approach to reduce the rate of waste generation from the saturated mordenite (adsorbent). The principle of bioregeneration adopted the mechanism of desorption after the use of adsorbents by empowering single culture of microorganism. To determine its capacity, activated minerals mordenite were used to treat water containing $2.29 \mathrm{ppm}$ of Iron and $2.47 \mathrm{ppm}$ of manganese for the first stage (Pre bio-regeneration). This artificial iron and manganese contaminated solution was used as a representation of ground water in Bandung area. The reactor used have continuous stream with up-flow direction. Iron and manganese removal efficiency respectively in the 1st stage of adsorption (before bio-regeneration process) reaches $95 \%$ and $97 \%$. After the 72 hour submergence process by cultivated Thiobacillus ferooxidan, ability of the adsorbent still fulfil the drinking water quality standard in Minister of Health Regulation No. 492 of 2010. The removal efficiency reached $85 \%$ for iron but not suitable for manganese which only reached $30 \%$ of removal. This bio-regeneration can be applied as much as 2 times rounds.
\end{abstract}

\section{Background}

Ground water is one of the sources of basic consumption people in Indonesia, especially West Java. The results of BPS 2019 showed that more than 42\% type of water sources used by the community came from ground water such as protected dug wells and pumping wells [1].

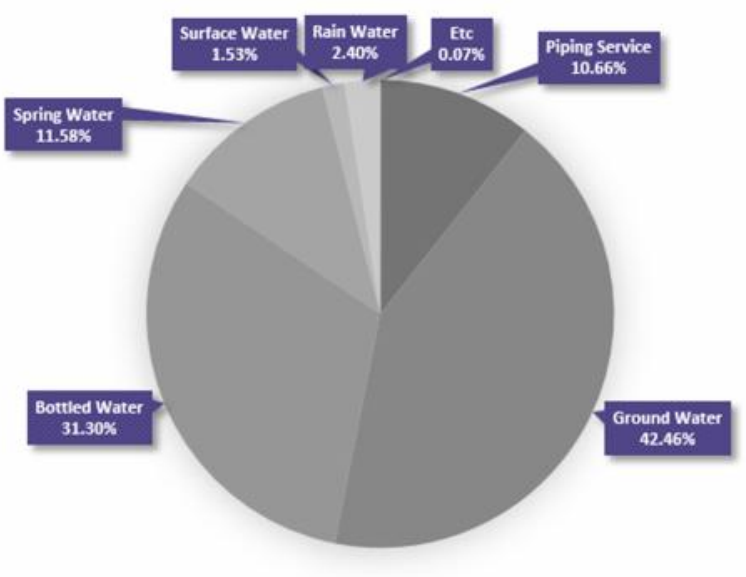

Fig. 1. Indonesia water source proportion

\footnotetext{
* Corresponding author: rifkanoorazizah $@$ gmail.com
}

Along with the many activities carried out by the community both from industrial and domestic activities, the potential for groundwater pollution becomes even greater. Contamination of concern is iron $(\mathrm{Fe})$ and manganese $(\mathrm{Mn})$ ion. Contaminated groundwater because of iron $(\mathrm{Fe})$ and manganese $(\mathrm{Mn})$ ions occurs naturally. The origin sources were anthropogenic emission including industrial residue, landfill leakage, and acid mine drainage. Well casing, pumping part, pipes and storage tanks spilled formation, can also contribute to $\mathrm{Fe}$ and $\mathrm{Mn}$ contamination [2]. In the lack of oxygen condition, iron and manganese reduced to their dissolved oxidation forms, $\mathrm{Fe} 2+$ and $\mathrm{Mn} 2+$, whereas in aerobic conditions they will be oxidized to their undissolved oxidation, Fe3+ and Mn4+ $[3,4]$. This condition makes the ground water will dissolve contaminants in the soil including inorganic contaminants so that the contaminants will be carried by the flow of water to fill ground water.

Mekarsari sub-district groundwater in Bekasi City, West Java, which was studied smelled and was reddish brown [5]. In addition to aesthetic issues, large doses of $\mathrm{Fe}$ can damage the intestinal wall because the body cannot excrete the iron. About 3-4 mg/L, Iron present in surface 
groundwater, but in some cases the contamination reach up to $15 \mathrm{mg} / \mathrm{L}$. Meanwhile, Mn content in the human body which causing seizures is present if in insufficient concentrations it is containing the blood or the toxicity substances present when excessive concentrations present in air, water, and food $[6,7]$.

Mordenite is one of the types of Transcarpathic zeolites found in nature, therefore they are considered economically accessible [8]. Mordenite minerals are also known to improve mineral adsorption properties [9]. Mordenite has a saturation point in the course of its use, this saturation point is widely modified through the adsorbent regeneration method including regeneration using chemicals, supercritical carbon dioxide, electrochemical, microwave, thermal and biological [10].

Bio-regeneration has been tested by involving desorption principle and biological removal. Most of demonstration occurs in offline systems. Bacteria as oxidation agent adsorbed organic matter in a closed-loop recirculating batch system [11]. Bio-regeneration adsorbents by the activity of the microorganism Thiobacillus ferrooxidans can produce protons and equivalent electrons, and consumed as substrate that perfectly mineralize to simpler molecules or ions, such as $\mathrm{CO}$, methane and $\mathrm{Cl}-$ [10]. For those reason, this research examined the extension of adsorbent by bio-regeneration through microorganism employment to treat ground water contaminated with $\mathrm{Fe}$ and $\mathrm{Mn}$.

\section{Experiment}

\subsection{Adsorbent}

Activated and regenerated mordenite minerals originating from Sukabumi Green Stone and crushed using a roller crusher and jaw crusher. Fragmented mordenite then sieved to obtain particles with a size of 40-70 mesh. Adsorbent then displayed and characterized by SEM (Scanning Electron Microscopy).

\subsection{Bacterial strain, cultivation and growth medium}

The bio-regeneration process is carried out using the role of leading microorganisms namely, Thiobacillus ferrooxidans. The bacteria's culture was obtained from the Bioprocess Laboratory of the School of Life Science and Technology ITB. A loop of bacteria was proliferated using $9 \mathrm{~K}$ medium and cultivated at an orbital shaker that been tuned $120 \mathrm{rpm}$ in room temperature for 14-20 days. The growth of strains monitored by spectrometer usage with wavelength $(\max \lambda)$ is $600 \mathrm{~nm}[12]$

\subsection{Reactor}

The fixed bed continuous reactor is 0.2 meters in height, 0.045 meters in diameter, with an up-flow mechanism ${ }^{13}$. Figure 1 shows the fixed bed continuous reactors being used during this study. Configuration set for continuous run. The top cover and the roof of the reactor designed to be opened and closed at any time, and equipped with porous media to ensure the flow is evenly distributed throughout the reactor. The running process is carried out with up-flow and continuous flow for 60 minutes. Samples taken every 5 minutes from the beginning to the end of the process. The running process is carried out in duplicate by using 2 reactors which are run simultaneously.

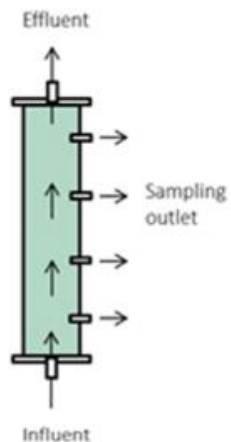

Fig. 2. Fixed bed continuous reactor for continuous run

\subsection{Regeneration process}

The process of biological regeneration done by mixing saturated mordenite size 40-70 mesh with $100 \mathrm{~mL}$ solution of the bacterium Thiobacillus ferrooxidan. The mixture stored in an incubator for 24; 48; and 72 hours. After that, mordenite is filtered with whatman 93 filter paper, washed with distilled water 3 (three) times, and dried in a $100^{\circ} \mathrm{C}$ oven for 24 hours [14].

\section{Result and discussion}

\subsection{Bacterial Growth}

By spectrometer usage, optical density is examined to mark off bacteria's multiplication inside the suspension. The maximum wavelength $(\max \lambda)$ is $600 \mathrm{~nm}$. Nemati in 1997 employed cell suspensions about $3.25 \times 107^{-4.475} \times$ 108 cells $\mathrm{mL}^{-1}$ of the reaction liquid, the temperature maintained in $35^{\circ} \mathrm{C}$, the effect of bacterial concentration on the oxidation rate of ferrous iron was studied [15]. Microorganisms adopt different mechanisms to interact and survive in the presence of inorganic metals. Various mechanisms used by microbes to survive metal toxicity are biotransformation, extrusion, use of enzymes, production of exopolysaccharide (EPS) and synthesis of metallothion $[13,14]$. Inoculated bacteria are as much as $10 \%$ in each liquid media. With $\mathrm{FeSO}_{4}-7 \mathrm{H}_{2} \mathrm{O}$ as an energy source for $\mathrm{T}$. ferrooxidans, it takes 26 days for the metal to dissolve [18]. Each T. ferrooxidans cell has a number of enzymes (E) capable of oxidizing $\mathrm{Fe}^{2+}$ (S) to $\mathrm{Fe}^{3+}(\mathrm{P})$ and that the enzyme has several binding sites for the substrate, the first substrate molecule bound to the enzyme changes the enzyme [15]. 


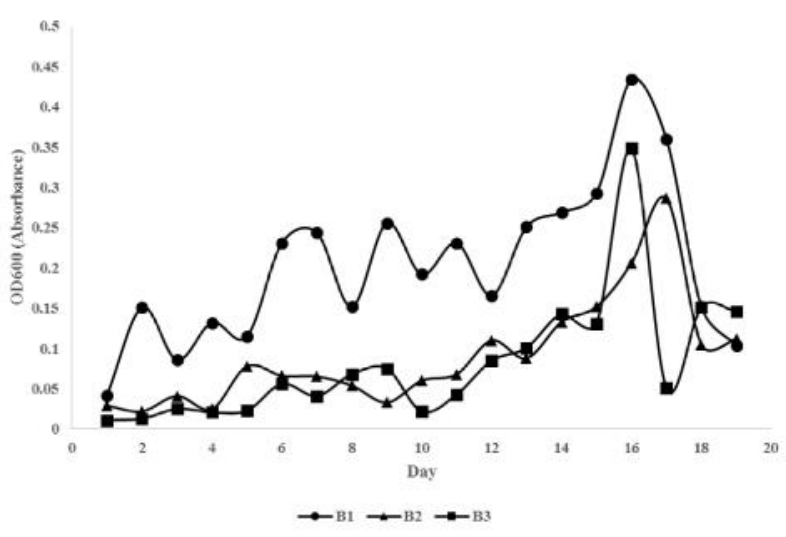

Fig. 3. Growth Pattern of Thiobacillus ferrooxidan

Based on observations the growth pattern of a bacterial on the liquid media shown in Figure 2, several growth phases can be seen. The growth of the bacterial in consortium population in the three variations represented by absorbance values ranged from 0.04 to 0.5 , where overall for all sources of plants experienced good growth with an exponential phase extending until the 15 th day even though there was a lag or adaptation phase which is characterized by a decrease in the absorbance value in the growth phase. The decrease in absorbance indicates that the bacteria have undergone an adaptation or acclimatization phase in the new liquid growth medium to be able to biosynthesize enzymes, essential metabolites needed to support their further growth, so the bacteria need time to make repairs to their cell damage. After the bacteria entering the exponential phase, the growth begins to rise steadily until it is time to die and the absorbance value decreases again. Bacteria that are in the exponential phase or logarithmic declination phase will be easier to even directly grow exponentially without going through the lag phase on the new substrate [10].

\subsection{Adsorben characterization}

SEM test result in Figure 3 shows that there is accumulation of compound which are adsorbed into the mordenite pore. Whereas in the regenerated adsorbent the enlarged pore looks and the blankets covering the pore have disappeared. The results are supported by previous studies stating that bioregeneration can be achieved by set a closed system to mix bacteria with saturated adsorbents [19].

\subsection{Adsorption capability}

\subsubsection{Pre-bioregeneration}

Graph indicates that the removal efficiency obtained will decrease as the adsorbent is used. The continuous process was able to remove iron and manganese and successfully meets the standards.

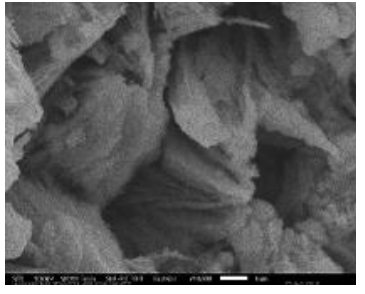

(a)

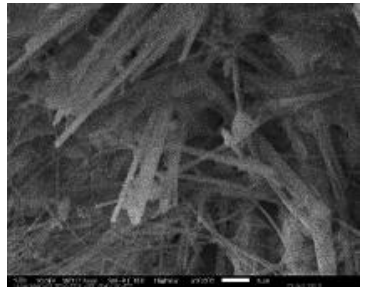

(b)
Fig. 4. SEM test result; (a) Pre-regeneration, and (b) Post-regeneration

According to several research, the presence of ions and other compounds in solution can affect the adsorption of adsorbates, while the removal of heavy metals in the adsorption process increases from the initial stage to 60 minutes [20]. From the experimental results show that iron removal has a higher level of efficiency than manganese.

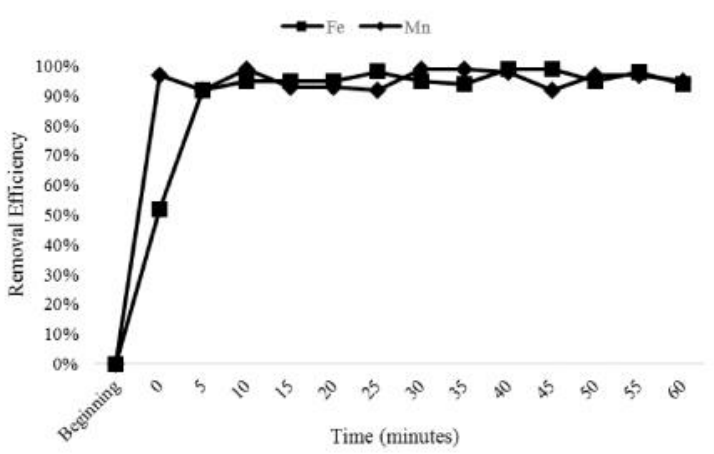

Fig. 5. Removal Efficiency of Iron and Manganese Prebioregeneration

The size of the manganese hydrated ionic diameter is almost the same as that of iron which are $0.876 \mathrm{~nm}$. If the average pore diameter of the mordenite is $10.4 \mathrm{~nm}$, both types of particles can enter the pore adsorbent mordenite and can be absorbed from the solution [21].

\subsubsection{Post-bioregeneration}

Bioregeneration processes could be effective by percise adjusting of numerous factors: the presence of microbial organisms capable of metabolizing the adsorbate, reversibility of adsorption process, the accurate microbial growth conditions including nutrients, temperature, dissolved oxygen, etc. and optimization of microbial and adsorbate concentration ratios [11]. A solution of each of the iron and manganese parameters was used to determine the level of removal efficiency as an effect of bio-regeneration. After mordenite has been used for several times the adsorption process, the adsorbent has been blocked or clogged so that regeneration efforts are needed to extend the life of the adsorbent. After biological regeneration is carried out for 72 hours, mordenite was then reused in the adsorption process and analyzed for the removal efficiency of the iron and manganese parameters. 
[22] adds that removal of heavy metals, such as $\mathrm{Fe}^{3+}$, $\mathrm{Mn}^{2+}, \mathrm{Zn}^{2+}$, and $\mathrm{Cu}^{2+}$ using zeolite adsorbents not only involve ion exchange mechanisms, but also allows the deposition of metal hydroxides from solutions. So both of these will affect the level of efficiency of the removal of the parameters studied.

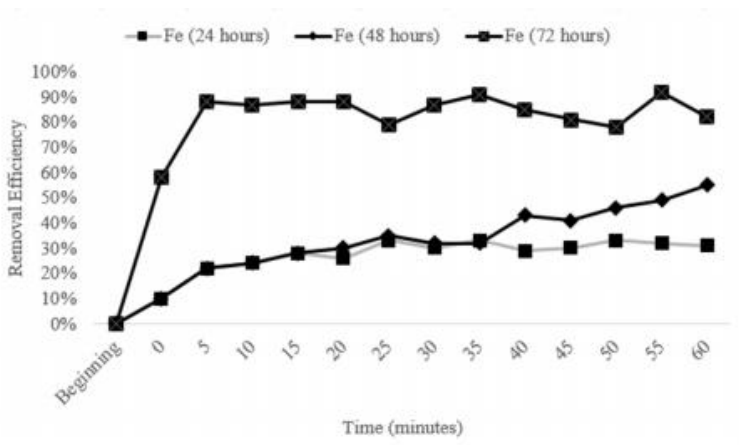

(a)

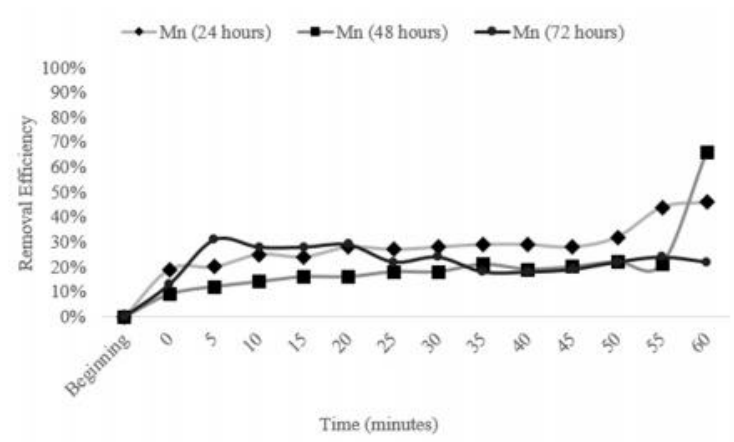

(b)

Fig. 6. Removal Efficiency of (a) Iron and (b) Manganese Postbioregeneration

Bioregeneration helps to improve adsorbent's abilities by utilizing microbes in regeneration. By the regeneration process, capacity and surface formation of the adsorbent influenced, but there are so many factors that influenced its regeneration [10]. Figure 5 shows that the ability of bioregeneration can restore the performance of adsorbents in the reduction of iron ions significantly at minute 5 for 72 hours immersion. Manganese ions do not apply that way because the most optimum removal can be achieved is around $35 \%$ in the 5th minute. This is considered to be inadequate to meet the permissible manganese requirements in Permenkes 492/2010 specifically $0.4 \mathrm{mg} / \mathrm{l}$.

Thiobacillus ferrooxidan plays an important role in this process, because Thiobacilli is a group of gram-negative chemoauthotropic bacteria that obtain energy from the oxidation of various inorganic sulfur compounds. Thiobacillus ferrooxidan which is an auotropic species can also oxidize iron (II) ions. This organism important in many mineral leaching processes, especially in bacterial leaching of sulfide ores for metal recovery [21, $22,23,24]$.

\section{Conclusion}

In general, the continuous process is able to remove iron and manganese and successfully meets the standards. The results showed that the mordenite activation process gives better results compared to mordenite without activation with a percent allowance above $80 \%$. The regeneration method carried out has been proven to be able to help improve the workability of adsorbents biologically by utilizing microbes to regenerate the capacity and surface of the adsorbent. Up to 2 times the regeneration period, Mordenite is still able to set aside iron to meet drinking water quality standards in Permenkes No. 492 of 2010 but not applied for manganese. The regeneration method is able to renew the surface of the adsorbent and eliminate compounds that close the pores to saturate the adsorbent by absorbing iron and manganese from the surface of the adsorbent, this is evidenced by the results of SEM and EDS tests.

\section{References}

1. BPS. Persentase Rumah Tangga Menurut Provinsi dan Sumber Air Minum 2000-2016. (2019). Available

at: https://www.bps.go.id/statictable/2014/09/10/1361/p ersentase-rumah-tangga-menurut-provinsi-dansumber-air-minum-2000-2016.html.

2. Marsidi, N., Hasan, H. A., Rozaimah, S. \& Abdullah, S. Journal of Water Process Engineering A review of biological aerated fi lters for iron and manganese ions removal in water treatment. $J$. Water Process Eng. 23, 1-12 (2018).

3. Baird, C. Environmental Chemistry. (W.H. Freeman and Company Editions, 2001).

4. Droste, R. Theory and Practice of Water and Wastewater Treatment. (John Wiley and Sons Inc, 1997).

5. Febrina, L. \& Ayuna, A. Studi Penurunan Kadar Besi (Fe) Dan Mangan (Mn) Dalam Air Tanah Menggunakan Saringan Keramik. J. Teknol. Univ. Muhammadiyah Jakarta 7, (2014).

6. Gonzalez-reyes, R. E., Gutierrez-alvarez, A. M. \& Moreno, C. B. Manganese and epilepsy: A systematic review of the literature. 53, (2006).

7. Services), U. D. (United S. D. of H. and H. Toxicological profile for manganese. Agency for Toxic Substances and Disease Registry. (2012).

8. Zamzow, M. J., Eichbaum, B. R., Sandgren, K. R. \& Shanks, D. E. Separation Science and Technology Removal of Heavy Metals and Other Cations from Wastewater Using Zeolites Removal Of Heavy Metals And Other Cations From Wastewater Using Zeolites. Sep. Sci. Technol. 25, 13-15 (1990).

9. Ćurković, L., Cerjan-Stefanović, Š. \& Filipan, T. Metal ion exchange by natural and modified zeolites. Water Res. 31, 1379-1382 (1997).

10. El Gamal, M., Mousa, H. A., El-Naas, M. H., Zacharia, R. \& Judd, S. Bio-regeneration of activated carbon: A comprehensive review. Sep. Purif. Technol. 197, 345-359 (2018).

11. Ferhan, C. Bioregeneration of activated carbon: A review. 59, 257-272 (2007). 
12. Silverman, M. P. \& Lundgren, D. G. STUDIES ON THE CHEMOAUTOTROPHIC IRON BACTERIUM I . AN IMPROVED MEDIUM AND A HARVESTING PROCEDURE FOR SECURING HIGH CELL YIELDS a C02-assimilating microorganism . Since then, a. (1958).

13. Satria, L. Penyisihan Ion Besi dan Mangan dengan Mineral Mordenite yang Diaktivasi dalam Fixed Bed Continuous Reactor. (2015).

14. Henrique, T., Souza, T. S. O. \& Foresti, E. Journal of Environmental Chemical Engineering Ammonium removal from land fi 11 leachate by Clinoptilolite adsorption followed by bioregeneration. Biochem. Pharmacol. 5, 63-68 (2017).

15. Nemati, M., Harrison, S. T. L., Hansford, G. S. \& Webb, C. Biological oxidation of ferrous sulphate by Thiobacillus ferrooxidans: a review on the kinetic aspects. 171-190 (1998).

16. Dixit, R. et al. Bioremediation of Heavy Metals from Soil and Aquatic Environment: An Overview of Principles and Criteria of Fundamental Processes. 2189-2212 (2015). doi:10.3390/su7022189

17. Wu, G. et al. A critical review on the bio-removal of hazardous heavy metals from contaminated soils : Issues, progress, eco-environmental concerns and opportunities. 174, 1-8 (2010).

18. Tyagi, R, Blais, J, Bulanger, B. Journal of Environmental Science and Health. Part A : Environmental Science and Engineering and Toxicology: Toxic / Hazardous Substances and Environmental Engineering Simultaneous municipal sludge digestion and metal leaching. 1361-1379 (1993). doi:10.1080/10934529309375947

19. Weber, A. S. \& Members, A. Abstract: introduction. 114, 1063-1076 (1989).

20. Lo, S., Wang, S., Tsai, M. \& Lin, L. Chemical Engineering Research and Design Adsorption capacity and removal efficiency of heavy metal ions by Moso and Ma bamboo activated carbons. Chem. Eng. Res. Des. 90, 1397-1406 (2011).

21. Novandy, D. Studi Kinetika dan Kapasitas Adsorpsi Ion Mangan dan Besi pada Adsorben Mineral Mordenite dengan Sistem Batch. (2014).

22. Goel, J., Kadirvelu, K., Rajagopal, C. \& Kumar, V. Removal of lead ( II ) by adsorption using treated granular activated carbon: Batch and column studies. 125, 211-220 (2005).

23. Ehrlich, H. \& Brierley, C. Microbial Mineral Recovery. (McGraw Hill Companies, Inc, 1990).

24. Barret, J., Hughes, M., Karavaiko, G. \& Spencer, P. Metal Extraction by Bacterial Oxidation of Minerals. (Ellis Horwood, 1993).

25. Agate, A. D. Recent advances in microbial mining. 12, 487-495 (1996).

26. Rawlings, D. E. Industrial practice and the biology of leaching of metals from ores The 1997 Pan Labs Lecture. 268-274 (1998). 